\title{
COMPARATIVE STUDY ON ELECTROPHORETIC PROTEIN PATTERN CHARACTERIZATION OF TILAPIA SPECIES IN THE RIVER NILE, EGYPT.
}

\section{Sabry S. EI-Serafy; Nassr-Allah H. Abdel- Hamide ; Mohammed H. Awwad and Mona S. Azab.} Department of Zoology, Faculty of Science, Benha University, Benha, Egypt.

Key words:Tilapia species, protein electrophoresis, plasma, muscle, monophylogenetic, River Nile.

\section{ABSTRACT}

This study deals with the electrophoretic characterization of Tilapia species using plasma and muscle proteins, as a taxonomically tool to differentiate Tilapia species that live in Egyptian habitat of the River Nile. These species are Oreochromis niloticuls ( $O$. niloticus), O. aureus ,Sarotherodon galilaeus ( $S$. galilaeus) and Tilapia zillii ( $T$. zillii). The data of electrophoretic protein separation indicated that each species has a characteristic specific pattern with more common bands for all species as well as species specific bands characteristic for each one. In this study, the protein of plasma and muscle were examined either treated with sample buffer or not treated. The results indicated that the protein pattern among the closer species exhibits common characters. In this regard, the obtained protein pattern of $O$. niloticus looks like that of $O$. aureus indicating a monophylogenetic origin of these species. Whereas, less degree of similarity was recorded between $T$. zillii and other species, indicating a genetic distance between this species and the rest of Tilapia species.

\section{INTRODUCTION}

Fishes constitute a principal component of aquatic habitat. It is a source of protein, calcium and other elements necessary for vital activities of human body. It also contributes about $6 \%$ of the total world protein supply and about $24 \%$ of animal protein (FAO, 1984). So that, a great attention has been given to study the Egyptian fish species. Fishes of family Cichlidae are randomly distributed throughout Africa, Central. America, northern half of South America and parts of India (Fryer and 
Iles, 1972). Tilapia species present in different parts of the world, but the origin of $O$. niloticus is the River Nile.

Tilapia species constitute the most important group of family Cichlidae that inhabiting the River Nile (Sharaf Eldeen and AbdelHamide, 2002). These fishes are important for the nutritional and socioeconomic development of tropical and subtropical regions (Oberst $e t$ al., 1993; Rajavarthini et al., 2000; Morals et al., 2001). Special attention has been given to Tilapia species for aquaculture as it is characterized by rapid growth 'rate, reasonable reproductive strategy and reproduce during the first year of their age (Abdel-Hamide, 1998; Haroun, 1999). There is a wide array of aquatic species to be accurately classified and their populations to be categorized for evaluation of aquaculture potential. In the River Nile, the original habitat of Tilapia, there is a need to characterize and to name the species that is useful for researchers, firmers and consumers (Pullin, 1996). Lagler et al. (1977) noted that illapia fishes exhibit a high degree of parental care and they are divided into mouth brooder's and susbstrate brooder. Trewavas (1984) distinguished three genera of Tilapia, which are mouth brooders i.e.. Sarorherodon and Oreochromis, and substrate brooder, i.e. Tilapia. Therefore, hybridization has been done between the genera of similar reproductive pattern of Tilapia fish population that live in the River Nile (El-Serafy el al., 2003). Many researchers studied skeletal muscle proteins (Myogens) of fish by using polyacrylamide electrophoretic techniques as one of the biochemical methods used to differentiate animal species (El-Serafy, 1994; Mamuris et al., 1999; Sharaf El-Deen and Abdel-Hamide, 2002 ; Berrini et al., 2006 ). They reported the efficiency of electrophoretic methods for species identification. They also added that these methods gave useful data in strain and phylogenetic identification (El-serafy, 1994; Shain, 1999 ; El-Serafy et al., 2003.). Also, methods based on DNA analysis have also been used (El-Serafy et al., 2003; Perdices et al., 2005). For these reasons the present study aims to use the protein electrophoresis as a tool to differentiate Tilapia species, and to define the phylogenetic relationship among the studied species.

\section{MATERIALS AND METHODS}

The fishes used in the present study were collected from El-Riyah E-Tawfequi [A branch of the River Nile] at Benha City. After fish killing by medullar transaction, the muscle samples were isolated from the dorsal epiaxial muscle. 


\section{Blood sampling:}

The fishes were wiped carefully especially in the region between the operculum and the gills, in order to avoid the haemolysis. To avoid the possible effect of anesthesia on blood parameters and its constituents, the fishes were not anaesthetized before blood sampling (Abdel-Hamide, 1994 ). The blood samples were collected by heart puncture in a lithiumheparinized tube to avoid blood coagulation. The blood samples were centrifuged two times at $1500 \mathrm{~g}$ (about 4000 r.p.m.) for 10 minutes. Thereafter, the blood plasma was separated carefully from the blood cells using micropipette. Then it was stored in deep freezer $\left(-20^{\circ} \mathrm{C}\right)$ until analysis.

II. Electrophoretic technique: -

Fractionation of protein in plasma and muscle were done using sodium dodecyl sulphate polyacrylamide gell electrophoresis ( SDSPAGE ). Sample treatment and gell preparation were done according to the method recommended by Laemmli (1970). The plasma and muscle protein samples were loaded without any treatment (untreated sample) or by incubation with an equal volume of sample buffer at $95{ }^{\circ} \mathrm{C}$ for ten minutes (treated sample). Each sample was loaded in a separate well. Protein samples were separated using a vertical slab electrophoresis unit at a current $30 \mathrm{~mA}$ for each gel. Protein was stained in a gel by comassie brilliant blue (Falk et al., 1996). Excess stain was removed in destaining solution until the bands become clearly seen and the background became colourless, then the gel was stored in $7 \%$ acetic acid. Protein bands were detected by densitometer using Hoefer GS 365 software. Band reading was done as a transmission mode.

\section{Statistical analysis:}

The data obtained in this study were presented as mean $\pm \mathrm{SE}$ (Standard error) Student $t$-test was estimated between every two species to show the significant differences (Pipkin, 1984). Similarity coefficient (SC) between fish species was estimated following the formula of Ferguson (1980)

$$
\mathrm{SC}=\frac{\text { Number of fractions of common mobility }}{\text { Maximum number of fractions in an individual }}
$$




\section{Plasma Protein:}

\section{RESULTS}

\section{I.1 Fractions Appearance:}

In each studied species, untreated electrophoretic plasma protein sample showed eleven fractions (Table 1 and Figs 1;3;5;7). Fraction number 1 presented with a percentage $100 \%$ in all Tilapia species. In $O$. niloricus, fractions number 6 and 8 appeared with the same percentage. Whereas the $2^{\text {nd }}$ and $7^{\text {th }}$ fractions showed a low percentage of appearance, so these bands are species specific.

Most protein fractions of $O$. aureus appeared with high percentages. The fractions number 1,3 and 7 appeared in all the tested fishes. Low percentages of appearance were recorded for fractions number 4,9 and 11 (Table 1 )

Five fractions of plasma protein of S.galilaeus appeared with a percentage of $85.71 \%$ (Fraction number 2,3,6,8 and 10). Only one fraction (number 5) appears with low percentage (42.86\%).

In $T$. zillii, the first and $7^{\text {th }}$ fractions appeared in all examined fishes. The last fractions (numbers 10 and 11) showed a low percentage of $28.57 \%$ and $42.86 \%$, respectively. Therefore, by viewing the plasma proteinogram of Tilapia species it could be possible to differentiate Tilapia species by. protein bands number $2,4,5,7,9,10$ and 11 which appeared in the proteinogram by different percentages among the studied species (Table 1). Protein polymorphic bands are presented anong Tilapia species (Numbers 1, 3 and 7).

Table (2) shows the percentage of occurrence of plasma protein fractions of Nile Tilapia species (treated electrophoretic samples), the plasina proteinogram are presented in Figures (2, 4,6 and 8). Similarly, eleven fractions were recorded in each Tilapia species. Also, in $O$. niloticus, most fractions appeared with a high percentage. Regarding $O$. aureus, six fractions appeared with percentage of $100 \%$; these are numbers $1,2,6,7,9$ and 10 . The plasma protein fractions of $S$. galilaeus have a percentage appearance of $100 \%$; these fractions are the first fraction and the last six ones (numbers $6,7,8,9,10$ and 11). So, these fractions are polymorphic.

T. zillii shows a special protein pattern in which three fractions disappeared (number 4,5 and 11). So, this protein pattern characterizes $T$. zillii from the other Tilapia species. From the obtained data, it could be possible to differentiate Tilapia species by using untreated plasma protein be better than using the treated one. 


\section{I.2 Relative mobility of Protein Fractions:}

The significant ( $I$-test) among different relative mobilities of plasma protein fractions (untreated electrophoretic samples) were presented in Table (4). When comparing $O$. niloticus and $O$. aureus, the relative mobilities of $3^{\text {rd }}, 4^{\text {th }}, 7^{\text {th }}, 8^{\text {th }}$ and $9^{\text {th }}$ fractions changed with significant differences.

Only the difference in the $1^{\text {st }}$ and $8^{\text {th }}$ fraction mobilities were found statistically significant in comparing $O$. niloticus and $S$. galilaeus. Concerning the comparison between $O$. niloticus and $T$. zillii, four fraction differed significantly [fractions numbers 4,5,7 and 8]. This indicates that they are polyphyltic species.

All fraction mobilities of $O$. aureus and $S$. galilacus did not differ significantly. The fractions numbers $1,4,5,10$ and 11 differed significantly between $O$. aureus and $T$. zillii. This means that these are dissinilar species and they are genetically differed.

Only the average value of the relative mobilities of the $4^{\text {th }}$ and $11^{\text {th }}$ fractions are statistically differed when comparing $S$. galilaeus and T. zillii; this also indicates polyphylogny.

Similarity coefficient (SC) of the relative mobility of protein fractions was calculated between the examined species. A high SC value was found between $O$. niloticus and $S$. galilaeus $(0.82), O$. aureus and S.galilaeus (1.0) and S. galileaus and T. zillii (0.82). Whereas, a low value of SC was recorded between $O$. aureus and $T$. zillii (Table 4 ). So, $T$. zillii is only closer to $S$. galilaeus. Whereas, the other Tilapia species show high SC which may indicate a monophylogeny of all Tilapia species except $T$. zillii which may be originated separately.

Concerning the comparison of treated samples between $O$. niloticus and $O$. aureus, the $2^{\text {nd }}, 8^{\text {th }}, 10^{\text {th }}, 10^{\text {th }}$ and $11^{\text {th }}$ fraction mobilities changed significantly. Fractions number $1,2,3,9$ and 11 show significant differences in its mobilities between $O$. niloticus and $S$. galilaeus. Only the relative mobilities of the $6^{\text {th }}$ and $9^{\text {th }}$ fractions changed significantly between $O$. niloticus and $T$. zillii; so, they are dissimilar species. Among $O$. aureus and $S$. galilaeus, the differences of the $8^{\text {th }}, 9^{\text {th }}$ and $10^{\text {th }}$ fractions were statistically significant.

Significant differences were noticed only when the $9^{\text {th }}$ and $10^{\text {th }}$ fractions were compared between $O$. aureus and $T$. zillii, whereas, the $4^{\text {th }}$, $5^{\text {th }}$ and $11^{\text {th }}$ fractions disappeared in the prescribed species. Similarly, a special protein pattern was noticed again between $S$. galilaeus and $T$. zillii, in which, the $4^{\text {th }}, 5^{\text {th }}$ fractions were not found. Only the mobility of 
the $6^{\text {th }}$ fraction differed between $S$. galilaeus and $T$. zillii. This difference was statistically significant. The rest of the fractions in $S$. galilaeus and T. zillii showed no significant differences.

Similarity coefficient (SC) of relative mobility (treated samples) was found high (0.73) when comparing $O$. aureus and $S$. galilaeus and $(0.64 \%) O$. niloticus and $O$. aureus. Whereas, low values of SC were recorded among $O$. nilolicus and T. zillii and O.aureus and T. zillii (table 6). This means that the species $O$. niloticus, $O$. curetus and $S$. galilaeus are derived from' one origin (Monophylogentic). Whereas. $T$. zillii displays another origin. So all tilapia species are polyphylogenetic, i.e.. they are derived from separate origins.

\section{I.3 Percentage (\%) Area of Protein Fractions:}

The data of \% area of each protein band (untreated sample) are represented in tables 7 and 8. By comparing $O$. niloticus and $O$. curreus. only the $3^{\text {rd }}$ and $11^{\text {th }}$ fractions percentage area differed with significant differences. Similarly, the percentage areas of the 3rd and 5th fractions were significantly differed between O.niloticus and $S$. galilaeus. Regarding O.niloticus and $T$. zillii only the $5^{\text {th }}$ fraction percentage area showed significant difference. The comparison between $O$. aurets and $S$. galilaeus showed a significant differences in fraction number 1,3 and 5. While the $3^{\text {rd }}$ and $5^{\text {th }}$ fractions differed significantly between $O$. aureus and $T$. zillii. But all compared fractions between S.galilaeus and T. zillii showed no significant differences, so they are closely related.

The comparison of percentage area of plasma protein fractions of treated electrophoretic samples as average $t$-values between different species were presented in Table ( 10 ) When comparing $O$. niloticus and $O$. aureus, the percentage area of the $1^{\text {st }}$ fraction showed a significant difference, but no differences in the other fractions, so they are monophyltic species Between O. niloticus and S. galilaeus, there are significant changes of percentage area of the $8^{\text {th }}$ and $11^{\text {th }}$ fractions only.

Concerning $O$. niloticus and $T$. zillii, significant differences were observed when comparing the $1^{\text {st }}, 2^{\text {nd }}$ and $6^{\text {th }}$ fractions. So they are genetically distant species. Comparing $O$. aureus with $S$. galilaeus only the $1^{\text {st }}$ fraction differed significantly. The difference between $O$. aureus and $T$. zillii showed significant differences of percentage area of the $10^{\text {th }}$, and $6^{\text {th }}$ fractions.

Regarding the differentiation between $O$. aureus and $S$. galilaeus, only the $\%$ area of the first fraction was differed significantly. The comparison between $O$. aureus and $T$. zillii showed highly significant changes of 
percentage area of the $6^{\text {th }}$ and $10^{\text {th }}$ fractions. When comparing $S$. galilaeus and T. zillii, the $1^{\text {st }}, 3^{\text {rd }}, 6^{\text {th }}$, and $9^{\text {th }}$ and $10^{\text {th }}$ fractions slowed significant differences.

\section{Muscle proteins:}

\section{II.I. Fractions Appearance:}

The muscle proteinograms of tilapia species (untreated sample) exhibited ten fractions ( Table 11 and Figs $9(1,13,15$ ). In $O$. niloticus fractions noumber 1,5 and 6 appeared in all examined fishes. so they are polymorphic bands. The $3^{\text {rd }}$ and $9^{\text {th }}$ fractions were not found.

The eighth fraction appeared with the same percentage in all species except in $O$. aureus, in which this fraction was not detected. In $O$. aureus, six fractions appeared with the percentage of $100 \%$; these are fractions number $1,2,4,5,6$ and 7 . But, the $8^{\text {th }}$ and $10^{\text {th }}$ fractions were not found in this fish species. (Table 11).

Regarding S.galilaeus, four fractions appeared in all the examined fishes $(100 \%)$. Whereas, one fraction, the last one was disappeared $\left(10^{\text {lh }}\right)$. No specific band could be detected.

Fractions numbers 3 and 8 distinguish $O$. niloticus and $O$. curreus from the other tilapia species, in which this fraction disappeared in all tested individuals of this species. While, fraction noumber 9 was absent in $O$. niloticus and $T$. zillii .So, T. zillii can be identified using this band. The last fraction $\left(10^{\text {th }}\right)$ disappeared in all the tested species cxcept $O$. niloticus, in which this fraction appeared in very low percentage.

The percentage of appearance of muscle protein fraction (treated electrophoretic samples) of Tilapia species were presented in Table 12 and the muscle proteinograms were depicted in Figs 10,12.14 and 16. Fractions from 1 to 5 of muscle protein of $O$. niloricus have the percentage of appearance $100 \%$. Only. the last fraction $\left(10^{\text {lh }}\right)$ was not observed in the muscle proteinogram, so it discriminates 0 . niloticus from the other fishes. While in $O$. curreus, the fractions from 4 to 7 existed in all tested individuals.

A part from the $4^{\text {th }}$ fraction, the fractions of $S$. galilaets. from $!$ to 5 and the $8^{\text {th }}$ were appeared with percentage of $100 \%$. Six muscle protein fractions of $T$. zillii were found in all the tested individuals; these fractions are number $1,2,4,6,7$ and 8 .

Except fraction number 3, the fractions from 1 to 7 appeared with high percentages in all the studied species. The $3^{\text {rd }}$ fraction distinguishes $T$. zillii from the other tilapias, as it appeared with $100 \%$ appearance in all species, except $T$. zillii, only $42.86 \%$ of the individuals have this fraction. 


\section{II.2. Relative Mobility of Protein Fractions:}

The relative mobilities of muscle protein fractions (untreated electrophoretic samples) of tilapia species were presented in tables 13 and 14. Comparing $O$. niloticus and $O$. aureus, only the $7^{\text {th }}$ fraction showed a significant difference.

When comparing the mobility of the different fractions between $O$. niloticus and $S$. galilaeus, it was found that the differences were statistically significant if comparing the $4^{\text {th }}, 5^{\text {th }}, 6^{\text {th }}, 7^{\text {th }}$ and $8^{\text {th }}$ fractions. So, they are widely arrayed species.

The fractions from $5^{\text {th }}$ to $8^{\text {th }}$ and fraction noumber 2 changed with significant differences when comparing the relative mobility between $O$. niloticus and $T$. zillii. Regarding $O$. caureus and $S$. galilaeus, the differences in the relative mobility were considered statistically: significant when the $1^{\text {st }}, 3^{\text {rd }}, 5^{\text {th }}, 6^{\text {th }}, 7^{\text {th }}$ and $9^{\text {th }}$ fractions were compared. indicating wide genetic distance. The fraction mobility changed with more highly significant differences between $O$. aureus and $T$. zillii when. comparing the bands noumber 2,3,6, and 7.The differences of the relative mobility values changed significantly when comparing the $1^{\text {st }}, 2^{\text {nd }}, 3^{\text {rd }}$, and $8^{\text {th }}$ fractions between $S$. galilaeus and $T$. zillii.

$O$. niloticus when compared with $O$. aureus, exhibited a high similarity coefficient, as a result of comparing relative mobility of muscle protein fraction (Untreated electrophoretic sample), the recorded SC value was 0.5 . Whereas, the SC between the rest of the species is low value; this indicates a low similarity.

The significant ( $t$-test) among different relative mobilities of muscle protein fraction (treated electrophoretic samples) of Tilapia species is presented in table 16 .All protein fractions statistically have a non-significant change when comparing $O$. niloricus and $O$. aureus. The comparison of the 2 nd and $4^{\text {th }}$ fractions between $O$. niloticus and $S$. galilaeus showed a significant difference in the relative mobility. But, the comparison of the other fractions is not significant.

The relative mobility of the $8^{\text {th }}$ and $9^{\text {th }}$ fractions was changed with significant differences between $O$. niloticus and $T$. zillii. But the comparison of other fractions between the same two species was not significant. Concerning $O$. aureus and $S$. galilaeus, the differences of fractions mobility were changed significantly when comparing the $2^{\text {nd }}$ and $4^{\text {th }}$ fractions. 
The mobilities of fractions numbers 7,8 and 9 were differed with significant difference between $O$. aureus and $T$. zillii. The rest of fractions show negligible differences.

By comparing the relative mobility of fractions numbers $4,5,7$ and 10 between $S$. galilaeus and $T$. zillii, the differences were found statistically significant. Meanwhile, the rest of fraction mobilities are slightly differed in the sarcoplasmic protein of the prescribed species.

According to the data presented in table 16 , the SC values of relative mobility of protein fractions are 1.0 and 0.8 which resulted from comparing $O$. niloticus with $O$. aureus and $O$. aureus with $S$. galilaeus, respectively. However, a low SC value (0.6) was recorded when comparing $S$. galilaeus with $T$. zillii.

II.3. Percentage (\%) area of protein fractions:

The percentage area of muscle protein fractions (untreated electrophoretic samples) of Tilapia species were presented in tables 17 and 18. The percentage area of the $1^{\text {st }}$ and $7^{\text {th }}$ fractions differed significantly when comparing $O$. niloticus with $O$. aureus, whereas, the differences of other fractions did not significantly changed.

Fractions numbers 1,6 and 8 have percentage area which are found significantly differed between $O$. niloticus and $S$. galilaeus.

Concerning $O$. niloticus and $T$. zillii, only, the percentage area of the $6^{\text {th }}$ fraction showed a significant difference; this is due to fractions missing in these species.

By comparing the significant differences of percentage area of each protein fraction ( Table 18 ), it was found that $O$. aureus and $S$. galilaeus have a five significantly differed bands which may reflect genetic distance. The comparison of $O$. niloticus and $S$. galilaeus yield four bands that significantly differed in the percentage area, also reflecting dissimilar genetic origin. Whereas, S. galilaeus when compared with $T$. zillii show three bands which were significantly differed in its $\%$ area.

The data presented in Table ( 20 ) show the $t$-values of percentage area of sarcoplasmic protein fraction (treated electrophoretic samples) of tilapia species. The comparison of percentage area of the $1^{\text {st }}, 3^{\text {rd }}, 4^{\text {th }}, 5^{\text {th }}$ and $6^{\text {th }}$ protein fractions between $O$. niloticus and $O$. aureus represented significant differences which my reflect variations in the protein content in these bands.

Concerning the comparison between $O$. niloticus and $S$. galilaeus, the differences were statistically significant in five bands $(I, 3,5,6$ and 
8). When comparing $O$. niloticus with $T$. zillii significant differences were recorded for the $\%$ area of bands numbers $1,3,7$ and 8 .

When comparing the percentage area of fractions noumber 4,5 and 6 between $O$. aureus and $S$. galilaeus, it was differed significantly. Regarding the last two species (S. galilaeus and T. zillii) the $5^{\text {th }}, 6^{\text {th }}$ and $8^{\text {th }}$ fractions percentage area showed significant changes,

\section{DICUSSION}

Tilapia (family: Cichlidae) is common fishes native to the fresh waters of Africa. They include the mouth brooding genera (Orechrmois and Sarotherodon) and substrate spawning genus Tilapia (Trewavas, 1991; Stiassny, 1991). Its population constitutes a bulk of fauna in the River Nile. Their species distributed all over the river Nile habitat with some degree of dominance.

The monophyly of all Tilapia species (family Cichlidae) has been proved by Oberst et al. (1993 and 1996).

Lovshin (1982) recorded that the systematic distance between species is the reason for a reproductive behaviour barrier. In the present study, the two genera. Sarotherodon were found to be more closely related to each other. The evidence of this degree of similarity may be due to that these two obvious genera related to the same group with mouth brooding reproductive behaviour. Whereas, the results indicated a lesser degree of similarity between genus Tilapia and the other two genera, resulted from the differed reproductive behaviour of genus Tilapia (substrate spawning).

Electrophoretic techniques have been used to estimate genetic distances and taxonomic relationships among several groups of organisms including fish (Haroun, 1999; Hanfling and Brandl , 2000 ; Berrini ef al., 2006)

Hanfling and Brandl (2000) proved the monophyltic relationship between subfamilies of family Cyprinidae, which do not seem to be monophyltic, using allozyme electrophoretic technique. The results reported in the present work indicate species-specific patterns with common bands for all the studied species as well as specific bands characterizing each species. The monophyltic relationship of tilapia fish has been confirmed by Oberst et al. (1996), Zowail and Baker (1998), Yapi-Gnaore (2001) and Rognon and Guyomard (2003) by using several electrophoretic techniques including polyacrylamide gel electrophoresis, 
isoelectric focusing, inmunoelectrophoresis and allozyme electrophoresis.

Percentage appearance of plasma protein fractions indicated that the number of fractions are common for all the studied species without missing any fractions, this is due to all species are not exposed to any pollution. Sharaf-Eldeen and Abdel-Hanide (2002) investigated the exposure of $O$. niloricusis to some pollutants and found that six protein fractions were missing due to exposure to high level of copper.

The plasma protein fractions obtained in the present study show common polymorphic fractions for all the studied species. These fractions are noumber $1,3,6$ and 8 ; this proves the monophylogenetic relationship of tilapia species. The same observations were reported by Haroun (1999). White (2000) and El-Serafy et al. (2003).

Species-specific fractions for $O$. niloticus were obtained these fractions are nouniber $4,5,9,10$ and 11 , which show polymorphism. Fractions noumber $2,5,7$ and 10 were polymorphic and characteristic for $O$. aureus. Whereas fractions noumber $2.4,7,9,10$ and 11 were specific for $S$. galilaets, while fractions noumber 2,4.5,7 and 9 characterized $T$. sillii from the other tilapia species. These results are in agreement with those obtained by Haroun (1999) who used a biochemical technique for identification of three Oreochromis species and reported that each Oreochiomis species has a characteristic species - specific, isoelectric focusing pattern.

The comparison of serum proteinogram between the four species in the term of relative mobility indicated that there were similarity between $O$. niloticus and $S$. galilaeus $(\mathrm{SC}=0.82$ ) also between $O$. niloticus and $T$. zillii $(\mathrm{SC}=0.64)$ and between $T$. zillii and $S$. galilaeus ( $S C=0.82$ ). Also, high similarity was recorded between O.aureus and $S$. galilaeus. These results are in agreement with those obtained by Zowail and Baker (1998). The authors used the sera proteinograms to identify five species of fresh water fish (Sarotherodon galilaeus, Tilapia zillii, Oreochromis niloticus, Clarias lazera and Barbus bynni). The similarity coefficients were studied for the different species. The previous authors reported that the comparison of serum proteinogram between the five species in the term of relative mobility indicated that there were similarity between $O$. niloticus and $T$. zillii $(S C=0.75)$ also between $O$. niloticus and $S$. galilaeus $(\mathrm{SC}=0.63$ ) and between $\dot{T}$. zillit and $S$. galilaeus $(S C=0.75)$. On the other hand similarity was lower between the other species. 
The structure of blood serum proteins, muscle proteins haemoglobins as well as enzymes in blood and some organs appears to be variable (Kirpichinkove, 1981). These results are in agreement with the obtained results in which the muscle proteins differed from plasma proteins in two items: First, the muscle proteins were separated into ten fractions and to eleven fractions in plasma proteinogram, secondly, the disappearance of some fractions in the proteinogram of each species.

El-Gharabawy (1991) used electrophoresis technique to study the soluble proteins of muscles and skin of five sole species. The author found that some bands were obtained for each individual species and were considered as markers of these species. Also, several common protein bands were observed in all tested species. Also, White (2000) used protein electrophoretic technique to use skeletal muscle protein for investigating genetic variations of white bass Morone chrysops. The author found that there were relatively low levels of electrophoretic variations which characterize the species and low levels of allozyme variations appeared in all species in the same genus. Recenty. Berrini $e t$ al. (2006) used iso- electric focusing (IEF) and two dimensional electrophoresis (2-DE) of muscle protein to distinguish foure freshwater species.

In case of tilapia research, Oberst et al. (1996) studied the electropherograms of muscle protein of three species of genus tilapia: O. niloticus, $S$. galilaeus and $S$. melanotherom. They recorded speciesspecific protein profiles with common characteristic bands and according to the relation of these patterns. They placed the six investigated species into three groups with distinct band patterns $O$. niloticus with $S$. galilaeus, $S$. melanotheron with $T$. zillii and $T$. guineensis with $T$. dageti. Also, they found a closer relationship between the two species of genus tilapia. There was close relationship between genus Orechromis ( $O$. niloticus) and genus Sarotherodon ( $S$. galilaeus) and the genetic distance of genus Tilapia.

The obtained results of soluble muscle protein in the present study indicate the monophylogenetic relationship of all species in which, they all have the same number of protein fractions. Untreated muscle samples present five common fractions (numbers $1,4,5,6$ and 7 ) in all the studied species. Only the protein fraction number 8 was considered as speciesspecific fraction for $O$. niloticus, whereas, fractions numbers 2 and 3 characterize $O$. aureus from the rest of the species. Also, fractions 
numbers 2,3 and $\delta$ appeared equally in $S$. galilaeus and $T$. zillii. Whereas, protein.band number 9 distinguishes $S$. galilaeus from $T$. zillii.

Also, the obtained results of similarity coefficient indicate the polyphylogenetic relationship of different species. As well as there is relatively high similarity $(0.5)$ between $O$. niloticus and $O$. aureus. Meanwhile the recorded similarity coefficient between other different species was very low (0.2). indicating that these species belong to different genera.

Falk ef al. (1996) studied the proteinogram of skeletal muscle proteins, especially low molecular weight parvalbumins for different tilapis species. They indicated that, the $22 \mathrm{kDa}$-parvalbumin component was common to all species studied and probably characteristic for tilapia. Also, species of genus tilapia were characterized by the $24 \mathrm{kDa}$ component which was absent in the two other tilapia genera. They' also grouped the studied tilapia species into three groups. The first group included $O$. anreus, $O$. niloticus and $S$. galilaeus characterized by the expression of only one major parvalbumin component $(22 \mathrm{kDa})$. The second group includes $T$. zillii and $T$. busumana characterized by 13.5 $\mathrm{kDa}$ component. Whereas. $18 \mathrm{kDa}$ component occurs only in $T$. guineunsis and $T$. dagefi which have been placed as the third group.

Smith and McVeagh (2000) used allozyme electrophoretic technique to differentiate tooth fish species. They proved that the allozyme data show little genetic differentiation among species. In contrast, the microsatellite DNA data indicate significant genetic heterogeneity and demonstrate significant genetic differentiation among species. The same results were recorded for tilapia by Yapi - Gnaore (2001). The author used morphometric and Meristic characteristics, as well as, electrophoresis characterization and recent genetic techniques such as microsatellite and restriction fragments length polymorphism of mitochondrial DNA, to evaluate and describe fish characterization of three tilapia species ( $S$. melanotheron, $O$. niloticus and $O$. aureus). The same author also found that the molecular techniques provide god markers and significant genetic characterization for the studied species.

Species identification based on morphological criteria and protein analysis is the most reliable and widely used method. Species-specific banding patterns are typically generated by isoelectric focusing. This technique has proven to be reliable (Rehbein et al., 1995). Protein-based identification techniques become less reliable with fish. However, in 
some cases it is still possible to generate $\vec{a}$ banding pattern which enables identification (Berrini el al., 2006).

As an alternative to protein analysis, DNA-based identification techniques have been proposed and investigated. The molecular techniques based on PCR-RFLP analysis of the DNA have been extensively used for many analyses of fish ( Fernandez, 2001 ;Perdices $e t$ al ., 2005).

Farias et al. (1999) and El-Serafy et al. (2003) used restriction fragment length polymorphisms of nuclear and mitochondrial DNA- PCR products (RELPs / PCR) as a basis for examining relationships among tilapia species. They find out that tilapia species are polyphylogenetic species and some are monophylogenetic.

\section{Conclusion:}

The present study found a species specific protein pattern of tilapia species, by using protein fiactionation. Furthermore, the present study attains that the use of untreated sample gave data that is not completely differed in most cases from treated one. So, it is recommended to use untreated sample for electrophoretic identification of fish species. using of plasma and muscle proteinogram data are confirmatory for the species discrimination.

\section{REFERENCES}

Abdel-Hamide, N. A. H. (1994). Effect of some pollutants on biological aspects of Oreochromis niloricus.M.Sc. Thesis Faculty, of Science, Zagazig University ,Benha branch,pp198.

Abdel-Hamide N.A.H, (1998). Biology of reproduction of Oreochromis niloticus (Linnaeus, 1758).Ph.D Thesis, Faculty of Science ,Zagazig University ,Benha branch. 206 pp.

Berrini ,A. ; Tepedino,V.; Borromeo,V. and Secchi ,C. (2006).Identification of freshwater commercially labelled " perch " by isoelectric focusing and two -dimesional electrophoresis. Food chemistry,96:163-168. 
COMPARATIVE STUDY ON ELECTROPHORETIC PROTEIN 161 PATTERN OF TILAPIA SPECIES IN THE RIVER NILE, EGYPT

El-Gharabawy,M.M.(1991).Identification of five sole species from Egyptian Mediterranean waters by isoelectric focusing .Assuit .J. Agri. Sci.,22 (1):49-64.

El-Serafy,S.S. ( 1994 ). An electrophoretic study of muscle proteins of Oreochromis niloticus from three different Egyptian localities J.Egypt.Ger.Soc.Zool.Comp.,13 ( A ) :1-12.

El-Serafy. S. S. ;Awwad ,M.H. ; Abdel-Hamide .N.A.H. and Azab , M.S. (2003). Restriction fragment length polymorphisms ( RFLPs) of the small-subunit ribosomal DNA as a tool for identification of Tilapia spp. Egypt. J. Aquat. Biol.\& Fish.,7 ( 4 ) :465-482.

Falk ,T.M. ; Abban ,E. K. ; Oberst ,S.;Villwock ,W. ; Pullin , R.S.V. and Renwrantz, L.(1996). A Biochenical laboratort manual for species characterization of some Tilapiine fishes.ICLARM Educ.Ser.17:93p.

FAO (1984). News feature, reshaping world fisheries.Food and agriculture organization of the united nations.

Farias ,I.P. ; Orti ,G. ;Sampaio ,l.:Schneider .H. and Meyer ,A.(1999). Mitochondrial DNA phylogeny of the family Cichlidae : monophyly and fast molecular evolution of Neotropical assemblage . J. of Mol.Evol.,48:703-711.

Ferguson,A.(1980).Biochemical systematics and evolution .Glasgow,Blackie and London.

Fernandez, A. ; Garcia ,T. ; Asensio, L.;Rodreguez ,M.A. ; Gonzalez ,I. ;Hernandez ,p.e. and Martin, R.(2001). PCR-RFLP analysis of the internal transcribed spacer (ITS) region for identification of 3 clam species.J.Food Sci.,66:5.

Fryer, G. and Iles ,T.D.(1972) :The cichlid fishes of the great lakes of Africa: their biology and evaluation .T.F.H.Publ.,Neptune City, New Jersy. Also published by Oliver and Boyed, Edinburgh. 
Hanfling ,B.and Brandl (2000) Phylogenetics of European cyprinids : insights from allozymes .J.Fishhhh. Biol., 57 :265-276.

Haroun, M.R. (1999). Cross-breeding egyptian races of tilpias to produce more productive hybrids.Ph.D.Thesis, Fac. Sci., Tanat Univ.,pp193.

Kirpichnikov.R.S.(1981).Genetic basis of fish selection.Springer .BerlingHedilberg-New York $.410 \mathrm{pp}$.

Laemmli ,U.K.(1970). Cleavage of structural proteis during the assembly of the head of bacteriophage T 4 . Nature. 227:680-685.

Lagler ,K.E. ; Bardach .I.E. : Miller .R. and Passino .D.R.M.( 1977 ). Ichthyology.Ioln Wiley and Sons. Inc.,New York.

Lovshin, L.L.(1982).Tilapia hybridization .P279-308.In R.S.V.Pullin and R.H.Lowe-McConnell,eds. The biology and culture of Tilapias.ICLARM Con.Proc.,,7.Manila,Philipines.

Mamuris, Z.; Stamatis, C. and Triantaplyyllidis . C. (1999). Intraspecific genetic variation of striped red mullet (Mullus surmulatus L .) in the Mediterranean sea assessed by allozyme and random amplified polymorphic DNA (RAPD) analysis . Heredity , 83 : 30-38.

Morals ,R. ; Herrera ,M.T. ; Arenal A. : Cruz ,A. ;Hernandez ,O. ;Pimentel ,R. ; Guillèn .I. ;Martinez ,R. and Estrada , M.P.(2001).Tilapia chromosomal growth hormone gene expression accelerates growth in transgenic zebrafish (Danio rerio ) Elect. J. Biotech.,ISSN:0717-3458,4;2.

Oberst ,S.; Abban, E. K. and Viliwock,W. ( 1996 ). Biochemical and immunological markers for the discrimination of three Tilpaia species : T.zillii Gervais, T. guineensis Bleeker and T. dageti Thys v.d.Audenaerde (Pisces : Cichlidae) from West Africa.Aquacul.Res.,27:235-244. 
Oberst ,S.; Abban , E. K. ; Villwock ,W. and Renwrantz , L. (1993 ). tilapia plasma proteins and muscle parvalbumins as markers for species identification.Ger.J.Appl.Zool., 4:487-501.

Pipkin ,F.B.( 1984 ).Medical statistics made easy .Churhill Livingstone Edinberg, London, Melbourn and New York.

Pullin, R.S.V. ( 1996 ). World tilapia culture and its future prospects .In R.S.V. Pullin, Lazard . M. Legendre. I.B. Amon Kothias and D. Pauly( eds .) The third international symposium on tilapia in Aqnaculture.ICLARM Conf.Proc.. $\$ 1$.

Rehbein , H. : Mackie ,I.M. ; Pryde .S.; Gonzales-Sotelo,C. ;Perez-Martin , R.;Quinterio.I. and Rey-Mendez M.( 1995 ). Fish species identification in camned tuna by DNA analysis (PCRSSCP).Infn.Fischwirtsch, 42:209-212.

Rognon ,X. and Guyomard . R. (2003).Large extent of mitochondrial DNA transfer from Oreochromis aureus to Oreochromis niloticus in West Africa.Mol. Ecol..12(2):435.

Shain ,A.A.B. (1999). Phylogenetic relationship between the Characid Nile fish Alestes dentex .Cyprinid Barbus bynni. Labeoo niloticus, and the introduced grass carp Clenopharyngodon idella elucidated by protein electcrophoresis.J.Egypt.Ger.Zool.,29 (B) $: 21-42$.

Sharaf -Eldeen, K. and Abdel-Hamide,N.(2002).Sublethal effect of copper sulphate ,Malathion and Paraquat on protein pattern of Oreochromis niloticus. Egypt. J. Aquat. Biol. \& Fish., 6 (2) :167182.

Stiassny, M.L.J. (1991). Phylogenetic intrarelationships of the family Cichlidae: an overview, pp.1-35Cichlid fishes: Behaviour, Ecology and evolution, edited by M.H. A. Keenleyside. Chapman \& Hall, London. 
Trewavas,E. (1984). Tilapia fishes of the genera Sarotherodon , Oreochromis and Danakili. Brit. Mus:(: Nat.Hist.) London, 600pp.

Trewavas,E. and Teugels .G.G.(1991).Oreochromis and Saotherodon. In Check-list of the freshwater fishes of Africa (4) (Daget.J.Gosse : J.P.,Teugels ,G.G. \& Thys van den Audenaerde,D.F.E.,eds)Brussels:ISBN,Tervuren,MRAC:Paris: ORSTOM.

White, M .M.( 2000 ).Genetic variation in White Bass. Trans. Am. Fish. soc., 129:879-885.

Yapi-Gnaoré, V. (2001). Fișh genetics research in Cote dilvoire. In M V. Gupta and B.O. Acosta (eds .). 25-28.

Zowail . M. E. M. and Baker ,S.M.E. (1998).Genetic biochemical polymorphism and similarity coefficient of five species of freshwater fish ,J.Egypt.Ger:Soc.Zool..25(,C) :75-88. ". 


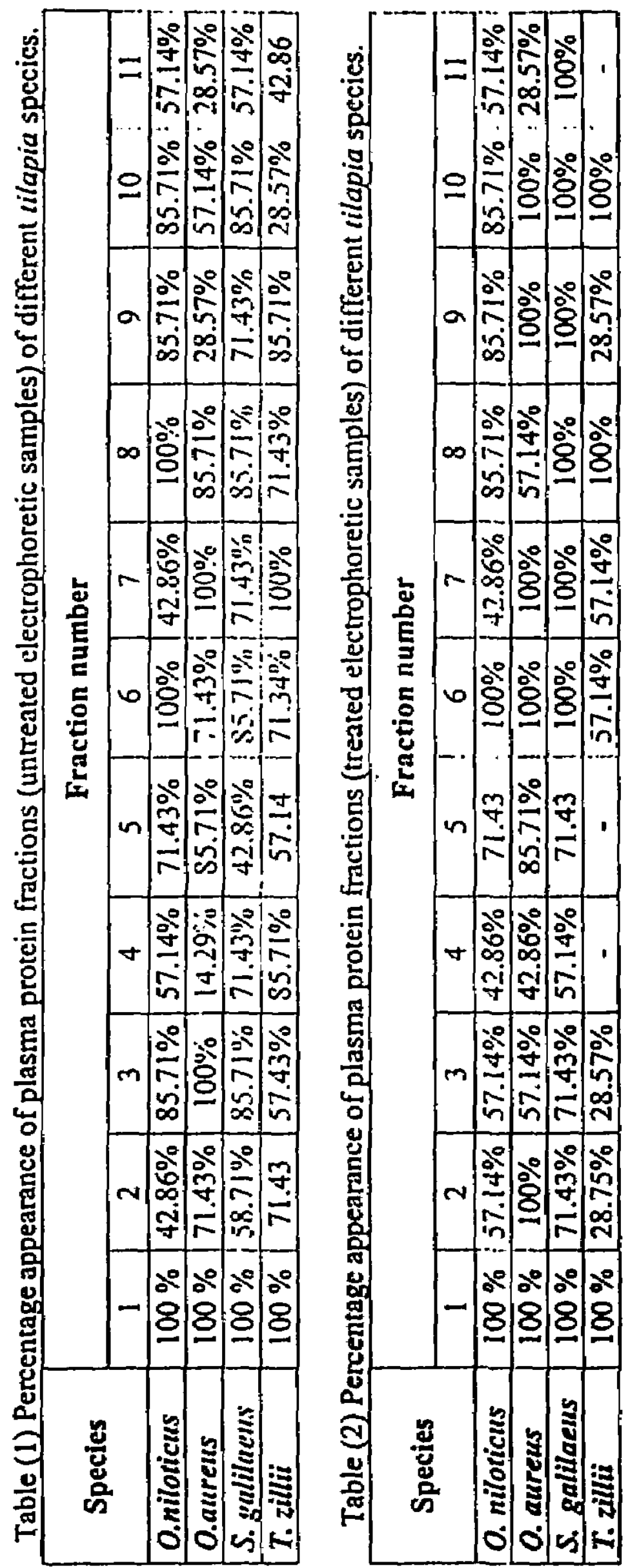




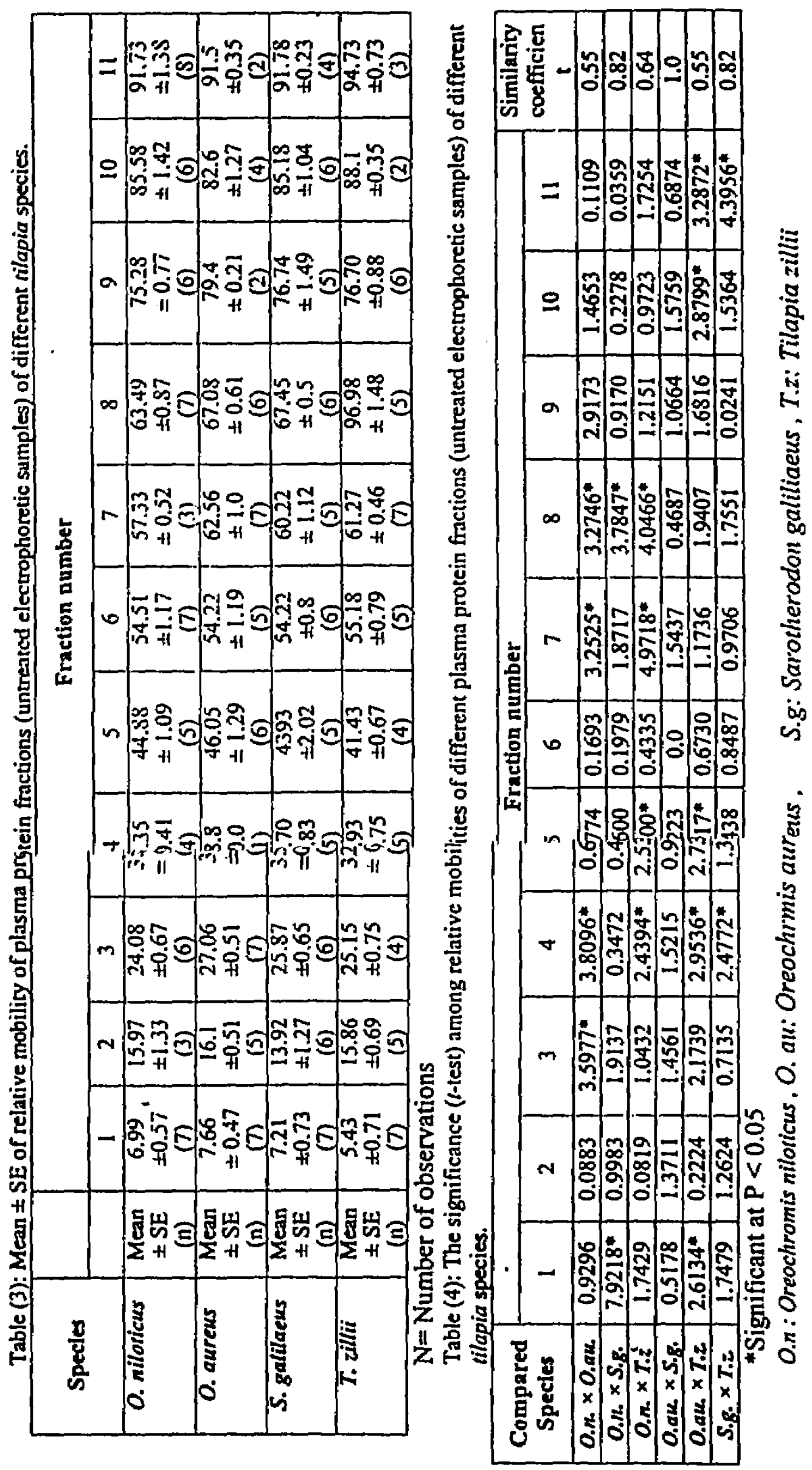



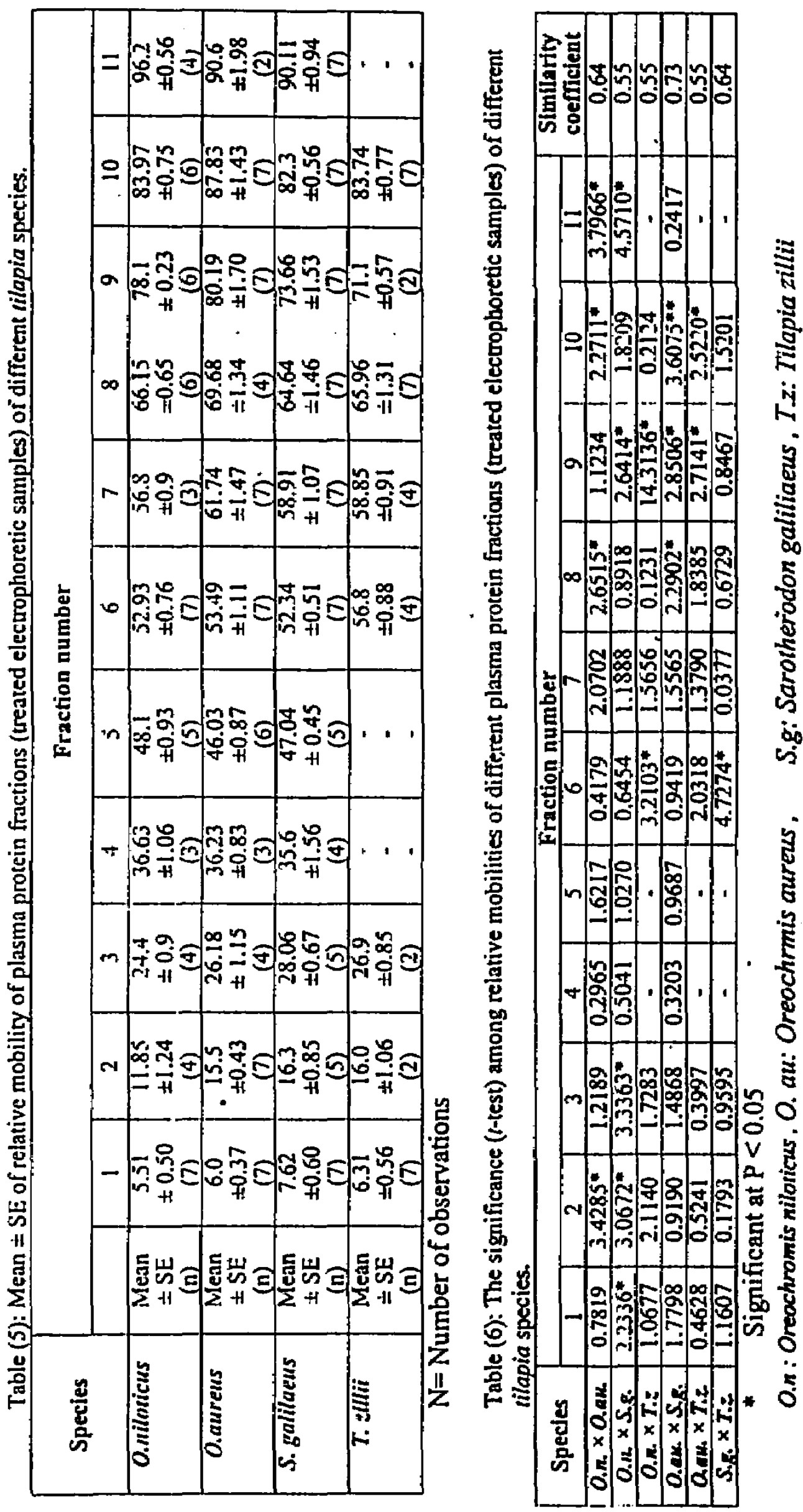

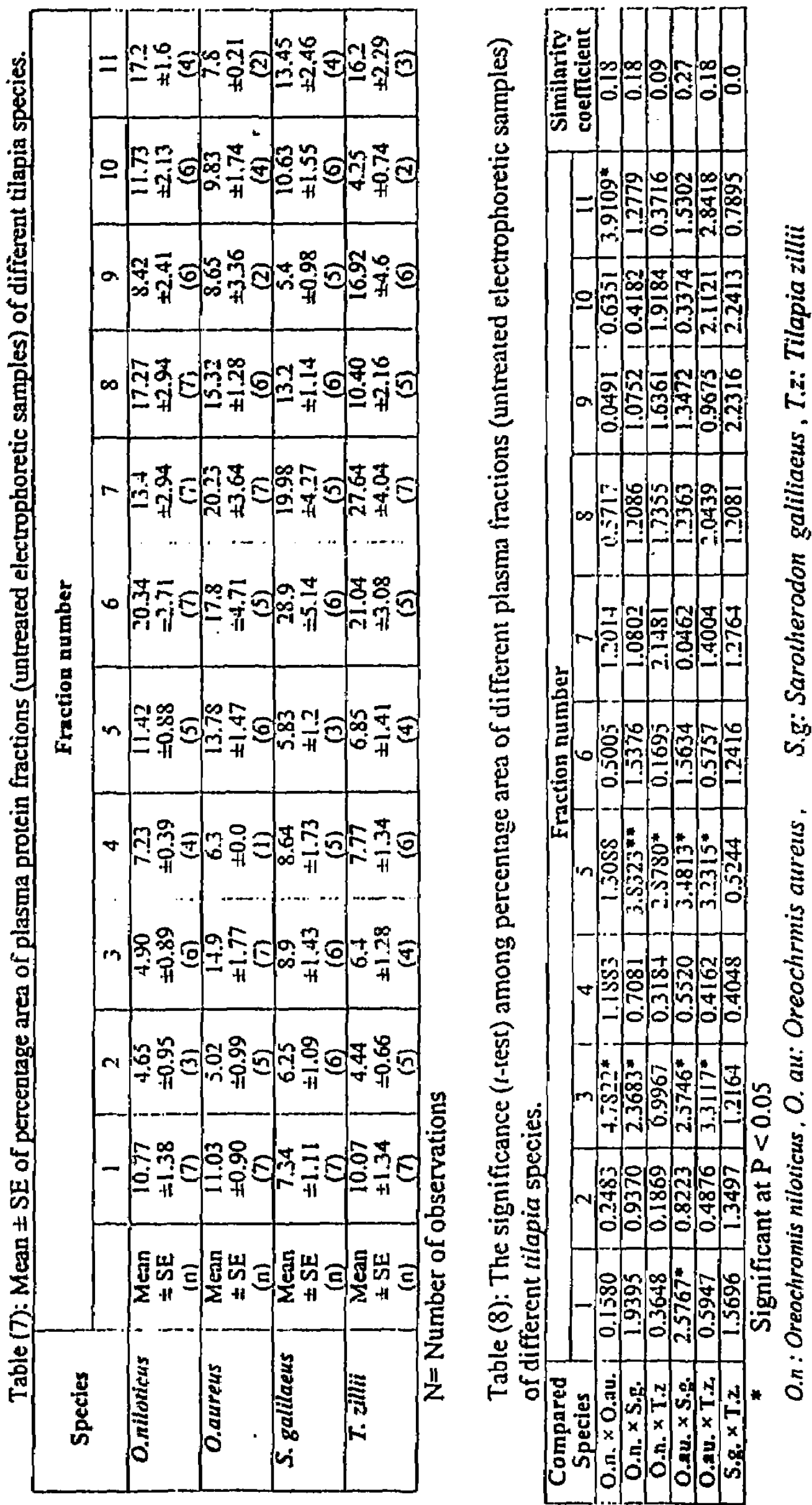

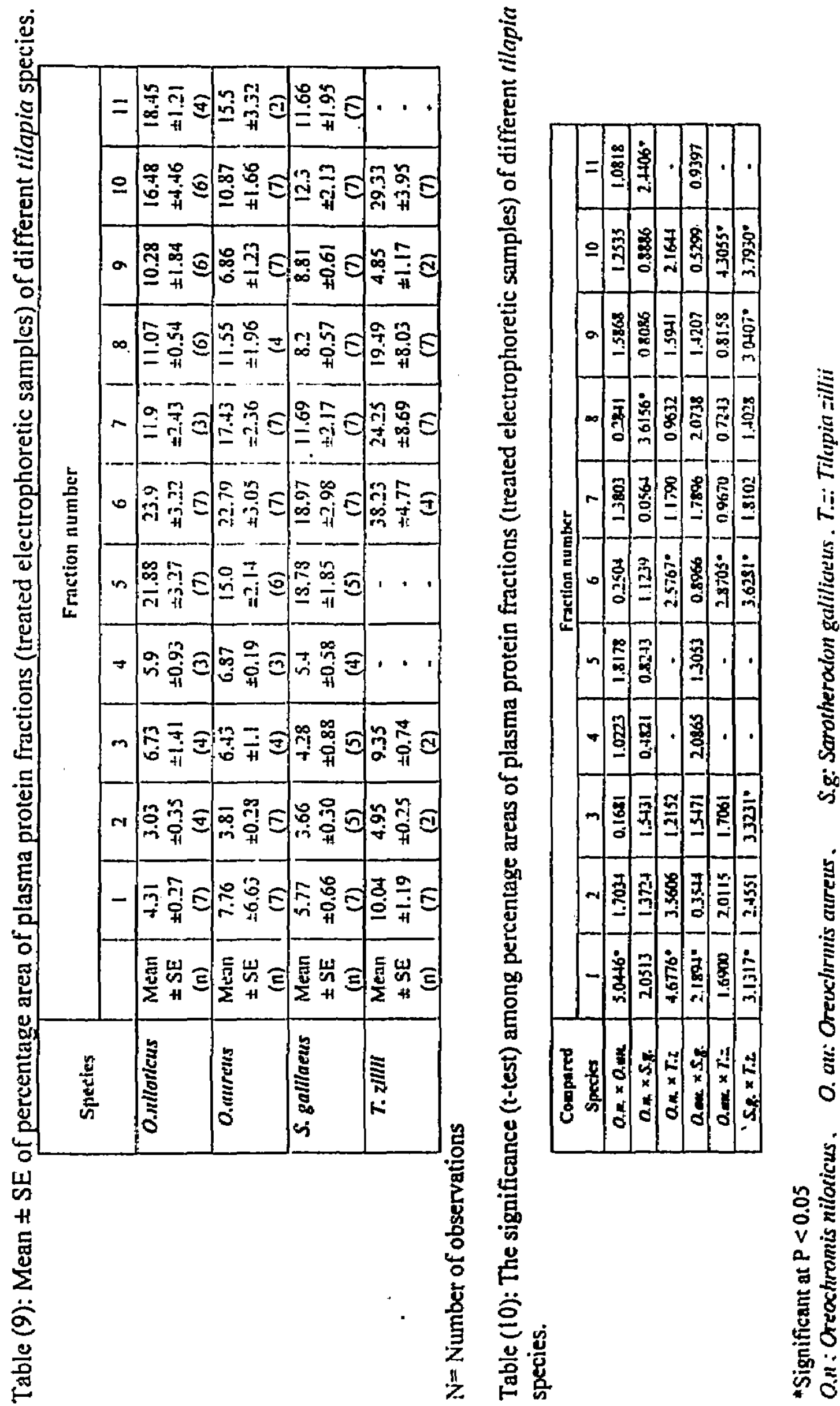


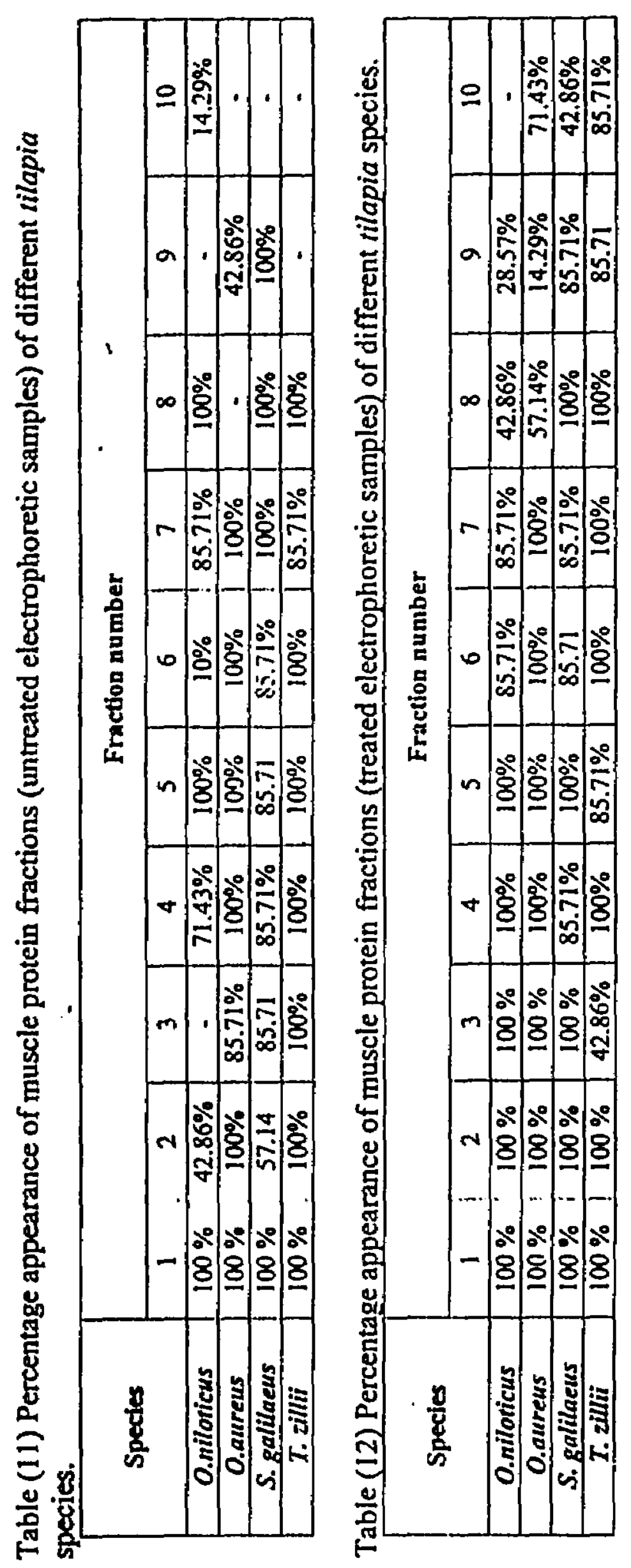



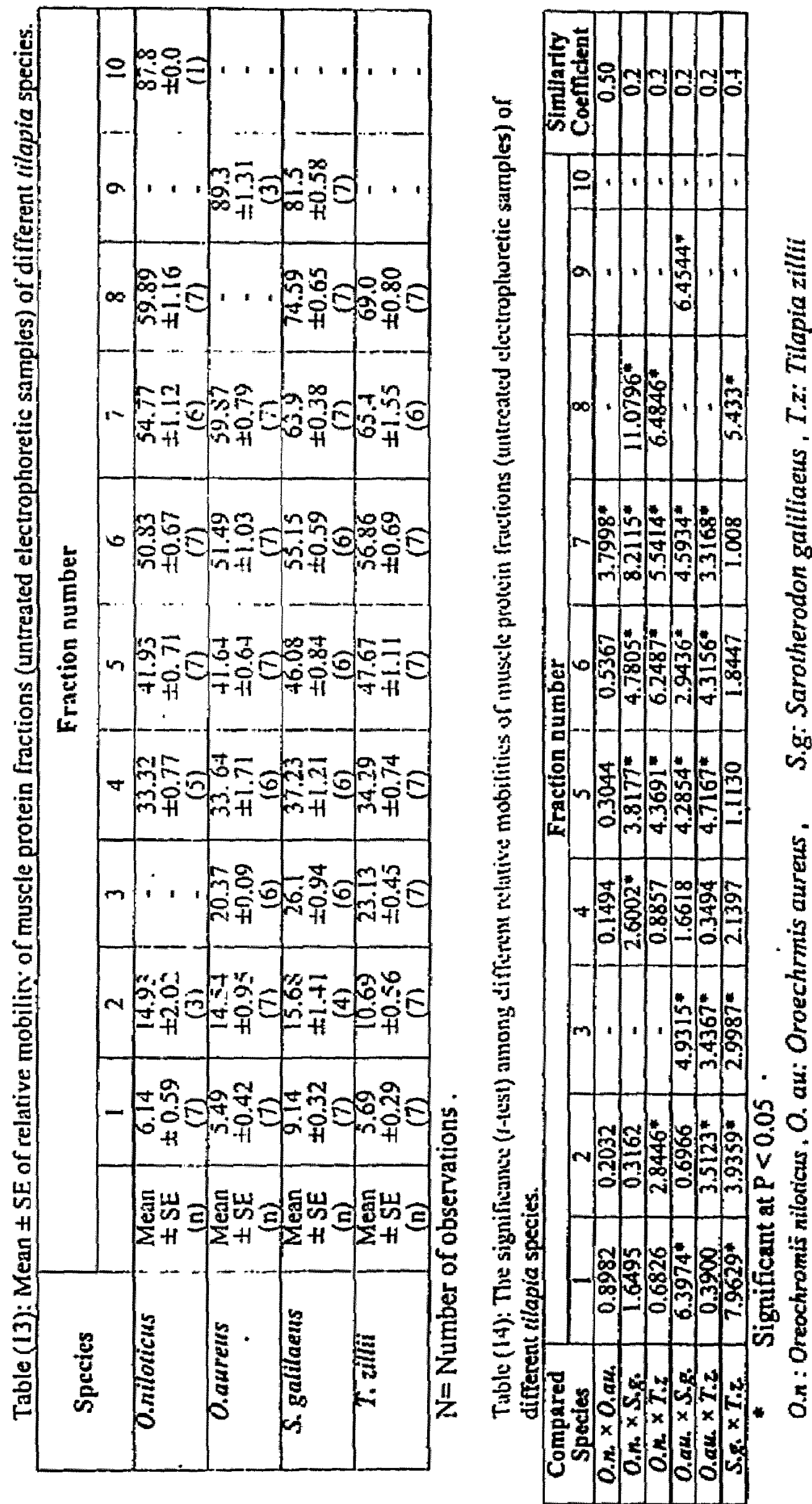

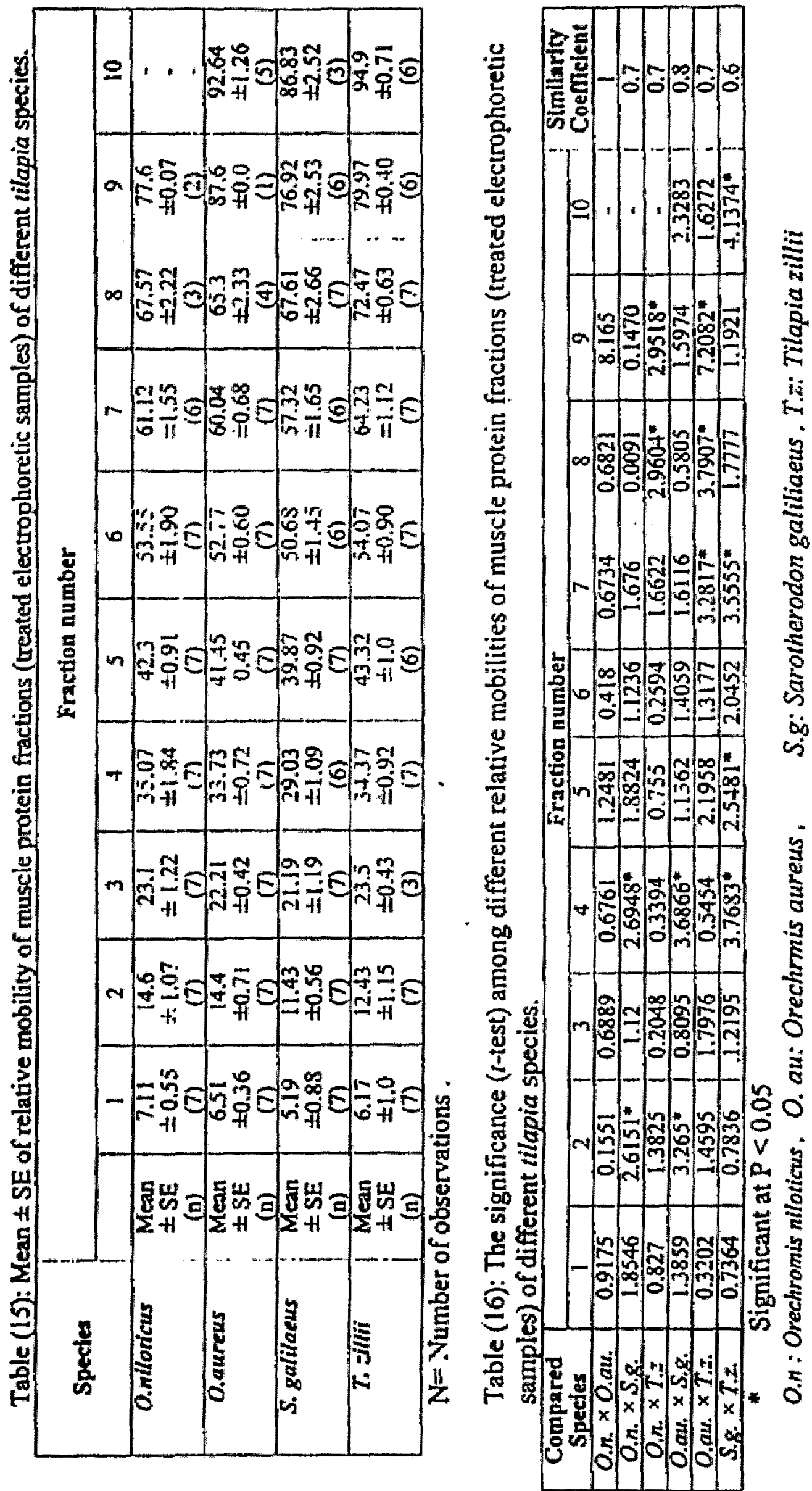


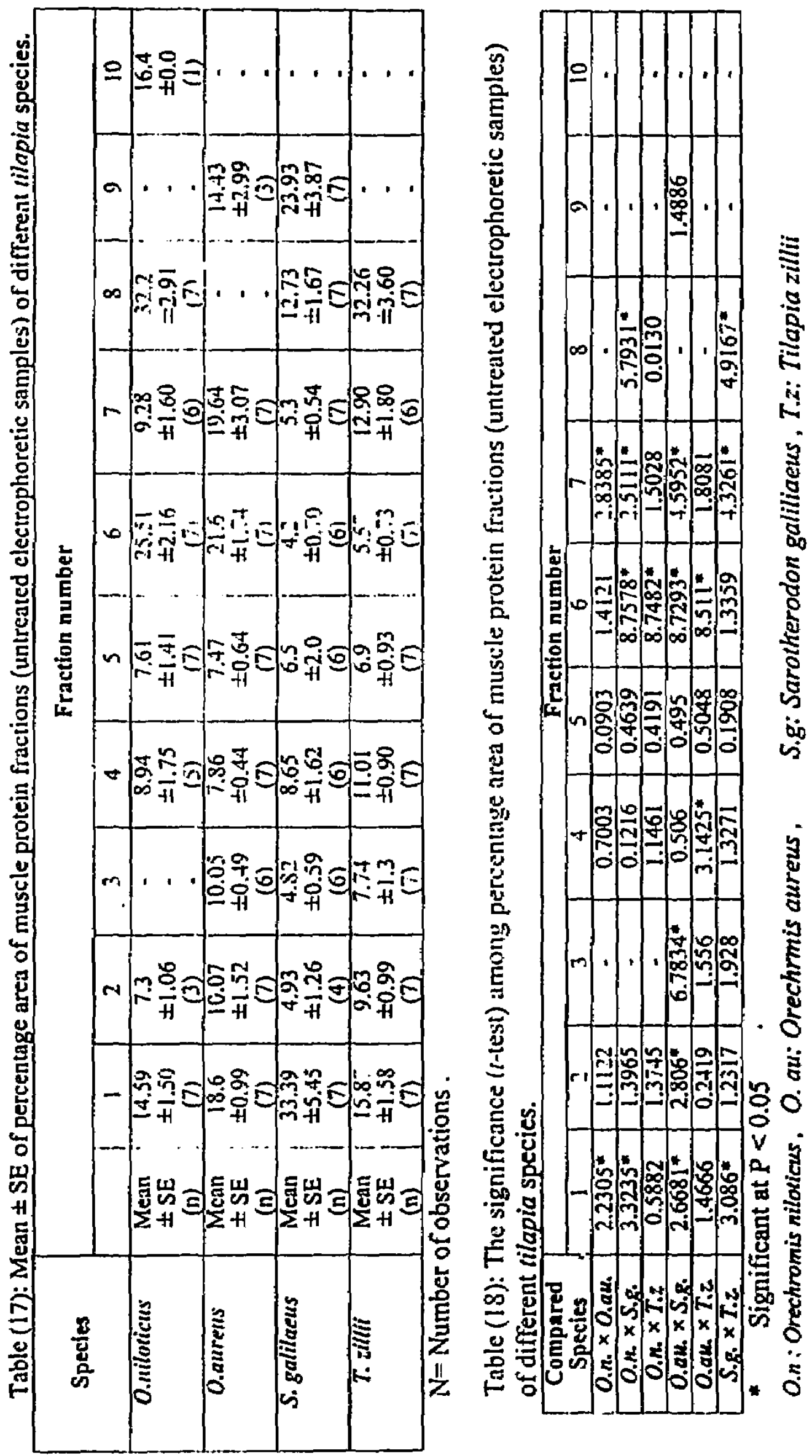




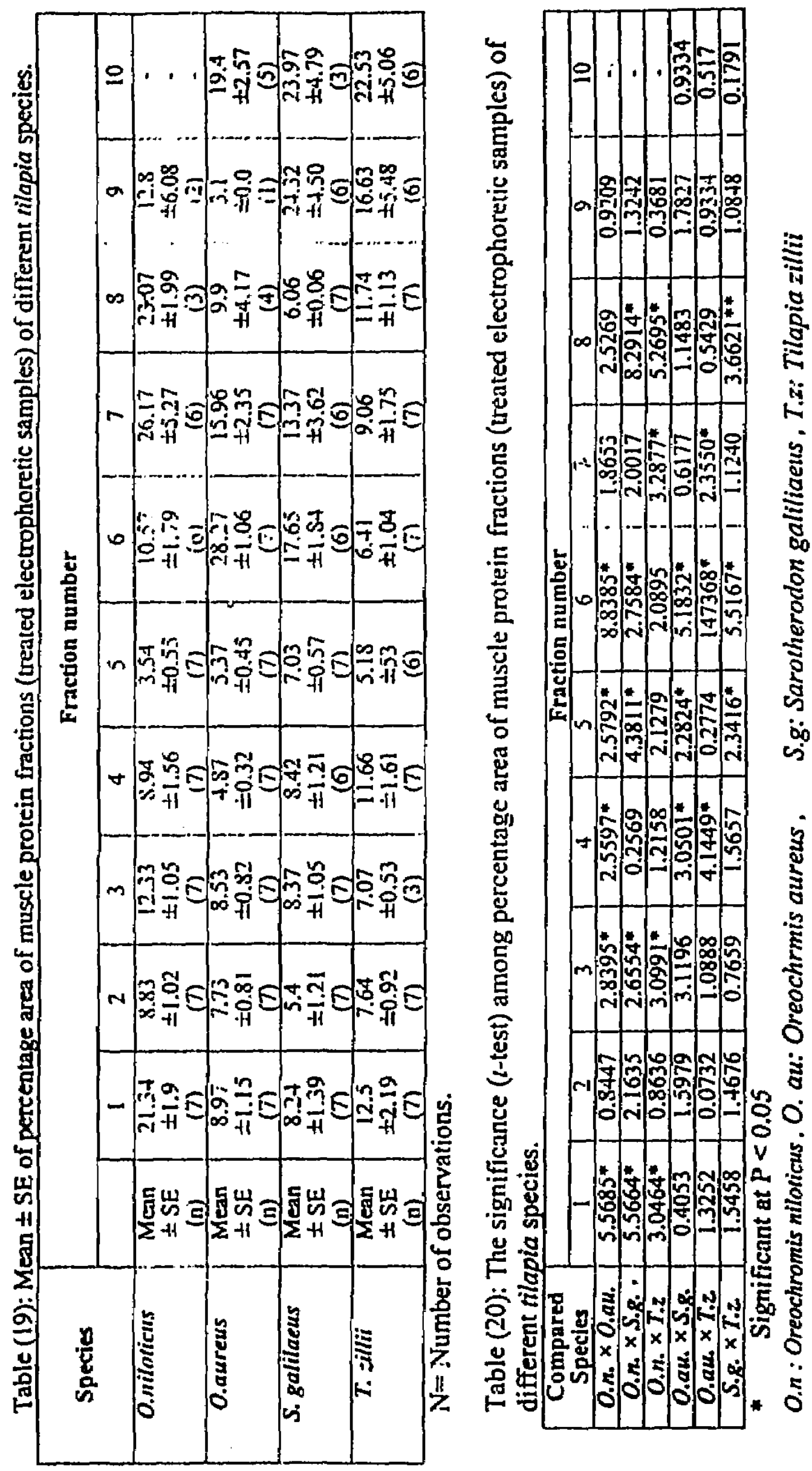



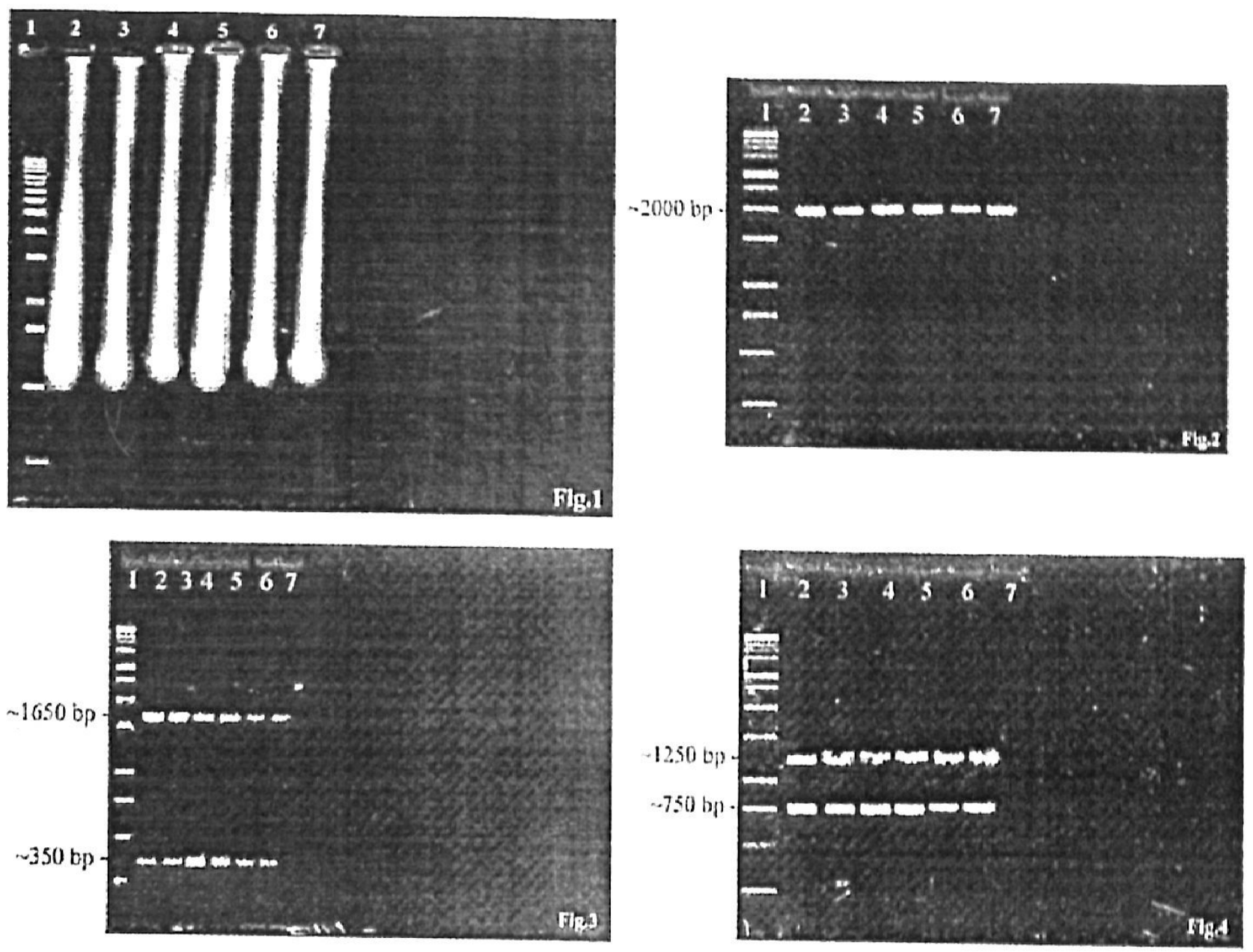

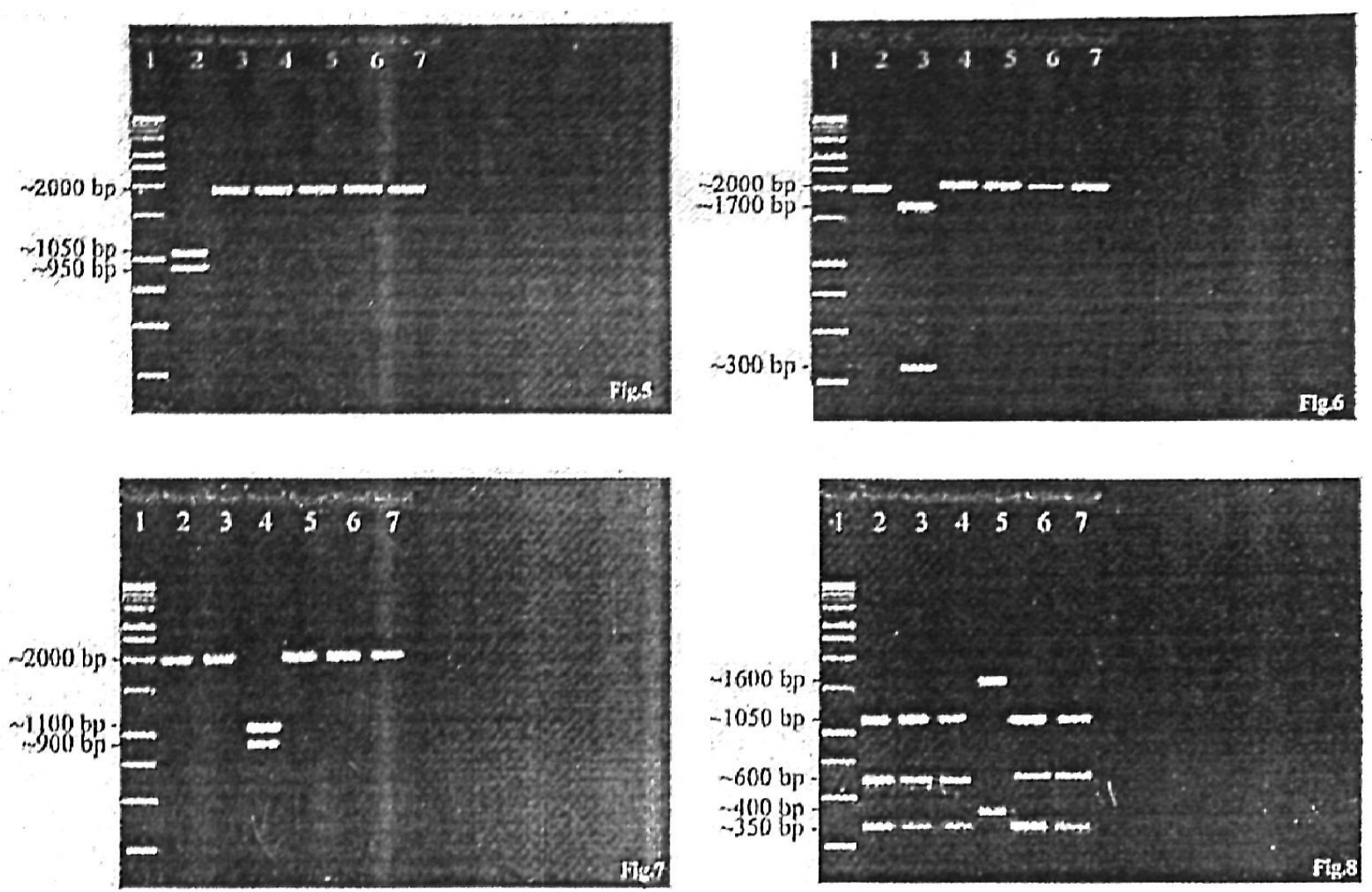

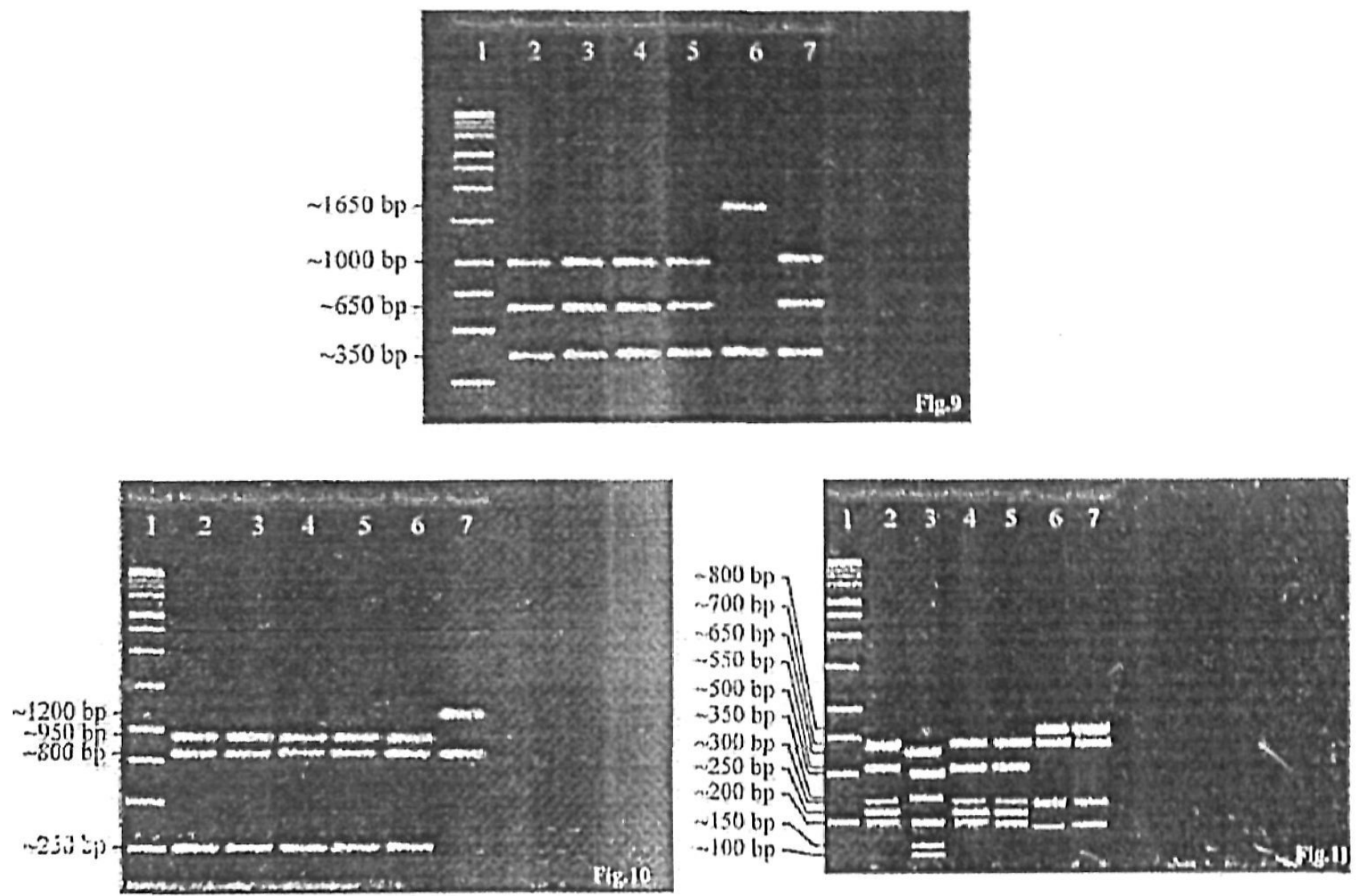